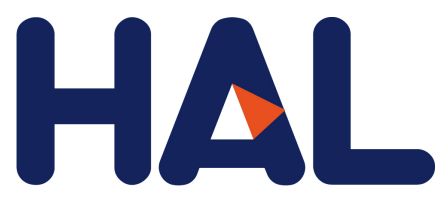

archives-ouvertes

\title{
Substituted Azafluorenones: Access from Dihalogeno Diaryl Ketones by Palladium-Catalyzed Auto-Tandem Processes and Evaluation of their Antibacterial, Antifungal, Antimalarial and Antiproliferative Activities
}

Nada Marquise, Floris Chevallier, Ekhlas Nassar, Michel Frédérich, Allison Ledoux, Yury S. Halauko, Oleg A. Ivashkevich, Vadim E. Matulis, Thierry Roisnel, Vincent Dorcet, et al.

\section{To cite this version:}

Nada Marquise, Floris Chevallier, Ekhlas Nassar, Michel Frédérich, Allison Ledoux, et al.. Substituted Azafluorenones: Access from Dihalogeno Diaryl Ketones by Palladium-Catalyzed Auto-Tandem Processes and Evaluation of their Antibacterial, Antifungal, Antimalarial and Antiproliferative Activities. Tetrahedron, Elsevier, 2016, 72 (6), pp.825-836. 10.1016/j.tet.2015.12.050 hal-01251206

HAL Id: hal-01251206

https://hal-univ-rennes1.archives-ouvertes.fr/hal-01251206

Submitted on 5 Jan 2016

HAL is a multi-disciplinary open access archive for the deposit and dissemination of scientific research documents, whether they are published or not. The documents may come from teaching and research institutions in France or abroad, or from public or private research centers.
L'archive ouverte pluridisciplinaire HAL, est destinée au dépôt et à la diffusion de documents scientifiques de niveau recherche, publiés ou non, émanant des établissements d'enseignement et de recherche français ou étrangers, des laboratoires publics ou privés. 


\section{Graphical Abstract}

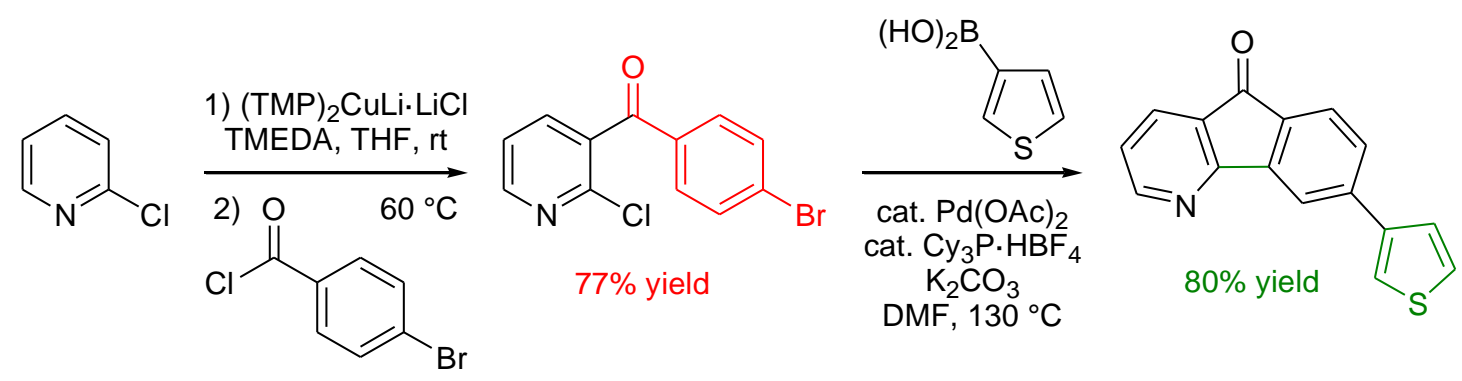

\section{Substituted Azafluorenones: Access from Dihalogeno Diaryl}

\section{Ketones by Palladium-Catalyzed Auto-Tandem Processes and}

\section{Evaluation of their Antibacterial, Antifungal, Antimalarial and}

\section{Antiproliferative Activities}

Nada Marquise, ${ }^{\mathrm{a}}$ Floris Chevallier, ${ }^{\mathrm{a}, *}$ Ekhlas Nassar, ${ }^{\mathrm{b}, \mathrm{c}, *}$ Michel Frédérich, ${ }^{\mathrm{d},{ }^{*}}$ Allison Ledoux,

Yury S. Halauko, ${ }^{\mathrm{e}, *}$ Oleg A. Ivashkevich, ${ }^{\mathrm{e}}$ Vadim E. Matulis, ${ }^{\mathrm{f}}$ Thierry Roisnel, $^{\mathrm{g}}$ Vincent Dorcet $^{\mathrm{g}}$ and Florence Mongin ${ }^{\mathrm{a}, *}$

${ }^{a}$ Chimie et Photonique Moléculaires, Institut des Sciences Chimiques de Rennes, UMR 6226, Université de Rennes 1-CNRS, Bâtiment 10A, Case 1003, Campus de Beaulieu, 35042 Rennes, France

${ }^{\mathrm{b}}$ Chemistry Department, Faculty of Women for Arts, Science and Education, Ain Shams University, Cairo, Egypt

${ }^{\mathrm{c}}$ Pharmaceutical Chemistry Department, Faculty of Pharmacy, Ibn Sina National College for Medical Studies, Jeddah, Kingdom of Saudi Arabia

' Pharmacognosie, Centre Interfacultaire de Recherche sur le Médicament (CIRM), Université de Liège, Avenue de l'hôpital 1, Bâtiment B36, B4000 Liège, Belgique

${ }^{\mathrm{e}}$ UNESCO Chair of Belarusian State University, 14 Leningradskaya Str., Minsk, 220030, Belarus

${ }^{\mathrm{f}}$ Research Institute for Physico-Chemical Problems of Belarusian State University, 14 Leningradskaya Str., Minsk, 220030, Belarus

${ }^{g}$ Centre de Diffractométrie X, Institut des Sciences Chimiques de Rennes, UMR 6226, Université de Rennes 1-CNRS, Bâtiment 10B, Case 1003, Campus de Beaulieu, 35042 Rennes, France

* Corresponding authors. Fax: +3322323 6955.

E-mail addresses: floris.chevallier@univ-rennes1.fr (F. Chevallier), ekhlass_nassar@hotmail.com (E. Nassar),M.Frederich@ulg.ac.be (M. Frédérich), hys@tut.by (Y. Halauko), florence.mongin@univ-rennes1.fr (F. Mongin). 
Keywords: azafluorenone, tandem process, palladium, antimalarial activity

\begin{abstract}
:
Substituted azafluorenones were synthesized from dihalogeno diaryl ketones under palladium catalysis by combining, in auto-tandem processes, Suzuki coupling and intramolecular arylation reactions. Different dihalogenated diaryl ketones, prepared by sequential deprotocupration-aroylation, were identified as suitable substrates to this purpose. Conditions were identified to allow successful syntheses of several 6-/7-arylated 4-azafluorenones, 1-substituted 4-azafluorenones, 2-phenyl-3azafluorenone and 4-phenyl-3-azafluorenone from 3-(bromobenzoyl)-2-chloropyridines, 3-benzoyl-4bromo-2-chloropyridines, 4-benzoyl-2,5-dichloropyridine and 4-benzoyl-2,3-dichloropyridine, respectively. Some of the synthesized compounds exhibit interesting biological properties.
\end{abstract}

\title{
Introduction
}

Many studies have been devoted to the access to azafluorenones, which are compounds of biological interest, for example in relation to their antifungal, ${ }^{1}$ antimicrobial, ${ }^{2}$ antimalarial, ${ }^{2 b, 3}$ and cytotoxic ${ }^{2 b, 4}$ activities, or else for their role in the treatment of neurodegenerative disorders. ${ }^{5}$ Lithiations $^{6}$ and multicomponent reactions ${ }^{2 \mathrm{~d}, 4 \mathrm{a}, 7}$ can notably be cited among the modern synthetic methods by which to access them. In 2010, an approach was developed by Kraus and Kempema who used 2-bromoaryl 3pyridyl ketones, prepared by reaction of 3-pyridyllithiums with 2-bromobenzaldehydes followed by oxidation, in intramolecular Heck cyclization reactions. ${ }^{2 c}$ In 2013, Ray and co-workers documented a two-step synthesis. Indeed, due to the facile oxidation of the corresponding $\alpha$-aryl-2-bromo-3pyridylmethanols, they successfully performed both oxidation and cyclization reactions within one palladium-catalyzed step. ${ }^{8}$

In the course of the development of 2,2,6,6-tetramethylpiperidido (TMP) bases for the deprotonative metalation of aromatic compounds, ${ }^{9}$ we have developed the use of $(\mathrm{TMP})_{2} \mathrm{CuLi} \cdot \mathrm{LiCl}$, prepared in situ from $\mathrm{CuCl}$ and LiTMP ( 2 equiv). ${ }^{10}$ Among the advantages of this lithiocuprate base, one can cite its possible use at room temperature and the possible trapping of the formed arylmetal species by aroyl 
chlorides to directly afford ketones. We have showed that, when applied to the synthesis of 2-chloro diaryl ketones, this method could be combined with direct arylation through $\mathrm{C}-\mathrm{H}$ bond activation by intramolecular transition metal-catalysis, ${ }^{11}$ to afford azafluorenones and related compounds in two steps. $^{12}$ Recently, we could achieve the synthesis of substituted azafluorenones by combining cyclization with cross-couplings such as Suzuki $^{13}$ and Heck $^{14}$ reactions in auto-tandem ${ }^{15}$ processes starting from diaryl ketones suitably substituted by two halogeno groups. ${ }^{16}$ Herein, the details of our synthetic investigations, including the testing of a large range of substrates, and the biological evaluation of the prepared compounds for their antibacterial, antifungal, antimalarial and cytotoxic activity are described.

\section{Results and Discussion}

The starting dihalogeno aroylpyridines were synthesized by deprotocupration-aroylation, as previously described. ${ }^{10}$ Upon treatment by the lithiocuprate $(\mathrm{TMP})_{2} \mathrm{CuLi} \cdot \mathrm{LiCl}$, generated in situ from $\mathrm{CuCl}$ and LiTMP (2 equiv), in tetrahydrofuran (THF) containing $N, N, N^{\prime}, N^{\prime}-$ tetramethylethylenediamine (TMEDA) at room temperature for $2 \mathrm{~h}$, the different chloropyridines were regioselectively deprotocuprated; their subsequent trapping with aroyl chlorides in general afforded the expected ketones. In the case of 2-chloro-4-iodopyridine, the arylcuprate proved unstable before the conditions required to perform its trapping (Table 1).

Table 1. Deprotocupration of 2-chloropyridines using in situ prepared $(\mathrm{TMP}){ }_{2} \mathrm{CuLi} \cdot \mathrm{LiCl}$ followed by aroylation. ${ }^{10 \mathrm{c}}$

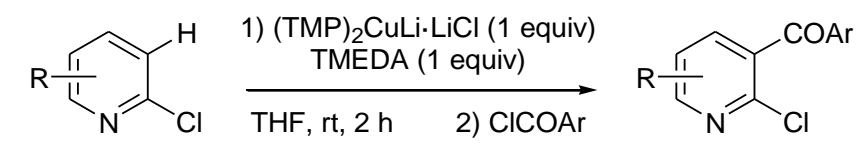

Entry Substrate $\quad$ ClCOAr




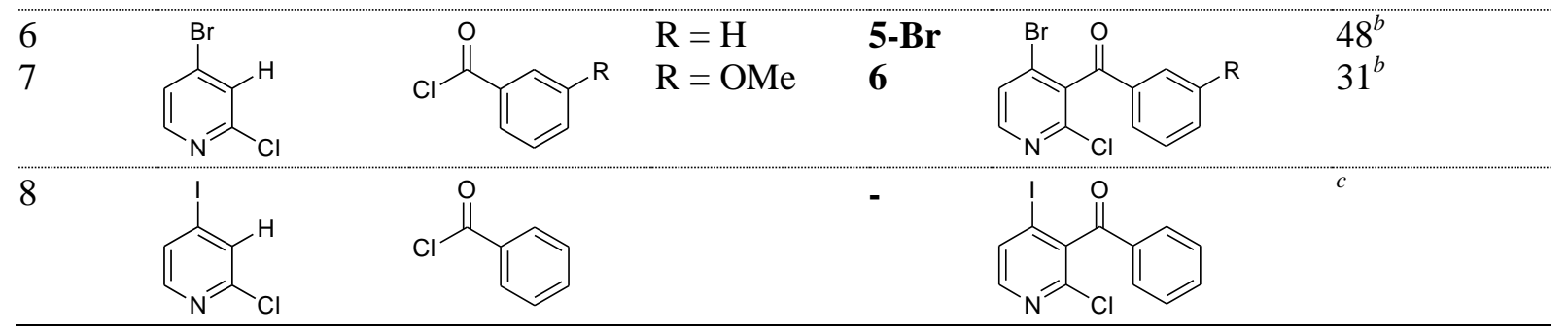

${ }^{a}$ Yield after purification by column chromatography. The rest is in general starting material. ${ }^{b}$ Trapping step performed at $60{ }^{\circ} \mathrm{C}$. ${ }^{c}$ Estimated $7 \%$ yield by performing the trapping step at rt; degradation at higher temperature.

We first focused on the synthesis of 4-azafluorenones substituted on their phenyl ring starting from 2chloro-3-(halogenobenzoyl)pyridines and using palladium-catalyzed Suzuki coupling-intramolecular arylation auto-tandem reactions (Scheme 1, Table 2).<smiles>[X]c1ccc(C(=O)c2cccnc2Cl)cc1</smiles>
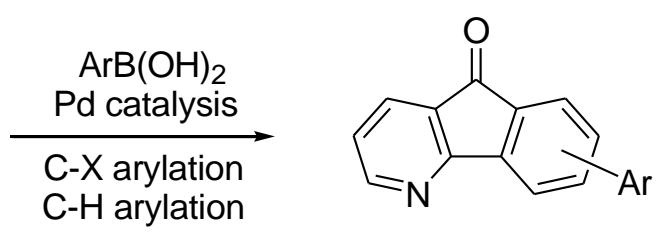

Scheme 1. Possible synthesis of 4-azafluorenones substituted on their phenyl ring using palladiumcatalyzed double arylation.

In our previous study aimed at cyclizing 3-benzoyl-2-chloropyridines to 4-azafluorenones, ${ }^{12}$ we employed a protocol inspired by conditions described for the cyclization of 2-chloro diaryl amines to carbazoles. ${ }^{17}$ This protocol used catalytic amounts of $\mathrm{Pd}(\mathrm{OAc})_{2}$ as transition metal source, electron-rich and bulky trialkyl phosphine $\mathrm{Cy}_{3} \mathrm{P}(\mathrm{Cy}=$ cyclohexyl $)$ as ligand, and $\mathrm{K}_{2} \mathrm{CO}_{3}$ as base, in $\mathrm{DMF}$ at $130{ }^{\circ} \mathrm{C}$.

Since similar conditions are suitable to perform Suzuki coupling reactions, ${ }^{13}$ we decided to attempt their use for the Suzuki coupling-intramolecular arylation of 3-(4-chlorobenzoyl)-2-chloropyridine (1Cl). We had previously observed the formation of bare 4-azafluorenone from 1-Cl (dechlorination) under these conditions; ${ }^{12}$ by performing the reaction in the presence of phenylboronic acid, we obtained a mixture containing expected 6-phenyl-4-azafluorenone (7a), but in a yield $<15 \%$ due to the competitive formation of 2-phenyl-3-(4-phenylbenzoyl)pyridine (bis-coupled product, about 33\% yield) and other (unidentified) coupled and/or dechlorinated products (entry 1). The Suzuki coupling being non-regioselective from 1-Cl, it was decided to rather involve 3-(4-bromobenzoyl)-2-chloropyridine (1- 
Br) in the reaction. Under the same reaction conditions, the functionalized tricycle $7 \mathbf{a}$ was this time isolated in $91 \%$ yield (entry 2).

It proved possible to extend the reaction to other arylboronic acids such as 4-hydroxyphenylboronic acid (entry 3), 3-thienylboronic acid (entry 4), and 2-benzo[b]thienylboronic acid (entry 5), and thus synthesize the corresponding 6-substituted 4-azafluorenones 7b-d in 41, 80 and $60 \%$ yield, respectively. The structures of the tricycles $7 \mathbf{c}$ and $\mathbf{7 d}$ were identified unambiguously by $\mathrm{X}$-ray diffraction (Figure 1, left and middle).

In contrast, using 2-furylboronic acid (entry 6) and 2,4-dimethoxy-5-pyrimidylboronic acid (entry 7) did not lead to the expected products. With the former, the main product was identified by gas chromatography (GC) as being 3-(4-(2-furyl)benzoyl)pyridine, i.e. the dechlorinated Suzuki coupling product. With the latter, 2-chloro-3-(4-(2,4-dimethoxy-5-pyrimidyl)benzoyl)pyridine, i.e. the Suzuki coupling product, proved by GC to be the main product whereas the expected derivative 7e was only detected (yield $<15 \%$ ) but could not be isolated.

Starting from 3-(4-bromobenzoyl)-2-chloro-6-(trifluoromethyl)pyridine (4) and phenylboronic acid, the expected azafluorenone $\mathbf{8 a}$ was formed in 51\% yield (entry 8). This moderate yield, when compared with that obtained using $\mathbf{1 - B r}$, is at least partly due to the competitive formation (estimated $17 \%$ yield) of the bis-coupled product, 2-phenyl-3-(4-phenylbenzoyl)-6-(trifluoromethyl)pyridine. The trifluoromethyl group could be responsible, by its electron-withdrawing effect, for the competitive cross-coupling observed on the pyridine ring. The formation of the product resulting from a double Suzuki coupling suggests a Suzuki cross-coupling reaction easier than the C-H arylation giving the azafluorenone.

3-(3-Bromobenzoyl)-2-chloropyridine (2) was next involved in the reaction with phenylboronic acid in order to see if a regioselective cyclization could be reached. In this case, both 7-phenyl-4azafluorenone (9a, 30\% yield) and 2-chloro-3-(3-phenylbenzoyl)pyridine (9a', 41\% yield) were isolated (entry 9), also suggesting a Suzuki coupling prior to cyclization. The compound 9a was the only 
azafluorenone obtained, showing a complete regioselectivity for the position far from the phenyl substituent (Figure 1, right). Using 4-hydroxyphenylboronic acid similarly led to the corresponding azafluorenone $\mathbf{9 b}$ in a moderate $41 \%$ yield (entry 10 ).

Table 2. Suzuki coupling-intramolecular arylation from the dihalides 1-4.

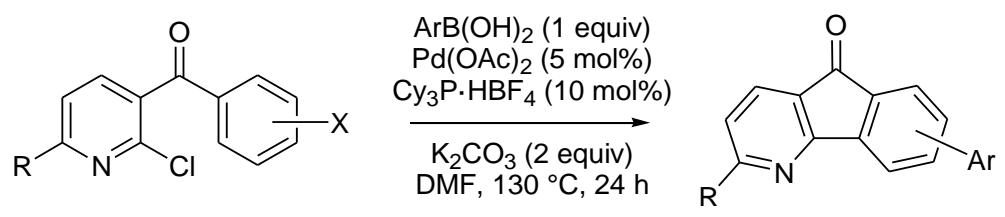

\begin{tabular}{|c|c|c|c|}
\hline Entry & Substrate & Product (Ar) & Yield $^{a}(\%)$ \\
\hline 1 & 1-Cl & $7 \mathbf{a}(\mathrm{Ph})$ & $<15^{b}$ \\
\hline 2 & 1-Br & $7 \mathbf{a}(\mathrm{Ph})$ & 91 \\
\hline 3 & $1-\mathrm{Br}$ & $7 \mathbf{b}\left(\mathrm{C}_{6} \mathrm{H}_{4}-4-\mathrm{OH}\right)$ & $41^{c}$ \\
\hline 4 & 1-Br & 7c (3-thienyl) & 80 \\
\hline 5 & 1-Br & 7d $(2$-benzo $[b]$ thienyl) & 60 \\
\hline 6 & 1-Br & - (2-furyl) & \\
\hline 7 & 1-Br & $\begin{array}{l}\text { 7e }(2,4-\text { dimethoxy-5- } \\
\text { pyrimidyl })\end{array}$ & $<15^{e}$ \\
\hline 8 & 4 & $\mathbf{8 a}$ & $51^{f}$ \\
\hline $\begin{array}{l}9 \\
10\end{array}$ & $\begin{array}{l}2 \\
2\end{array}$ & $\begin{array}{l}9 \mathbf{a}(\mathrm{Ph}) \\
9 \mathbf{b}\left(\mathrm{C}_{6} \mathrm{H}_{4}-4-\mathrm{OH}\right)\end{array}$ & $\begin{array}{l}30^{g} \\
41^{c}\end{array}$ \\
\hline $\begin{array}{l}11 \\
12\end{array}$ & $\begin{array}{l}3-\mathrm{Cl} \\
3-\mathrm{Br}\end{array}$ & $\begin{array}{l}-(\mathrm{Ph}) \\
\mathbf{1 0 a}(\mathrm{Ph})\end{array}$ & $31^{i}$ \\
\hline
\end{tabular}

${ }^{a}$ After purification by column chromatography. ${ }^{b}$ 2-Phenyl-3-(4-phenylbenzoyl)pyridine (about 33\% yield) and other (unidentified) coupled and/or dechlorinated products were also formed. ${ }^{c}$ The rest was starting material. ${ }^{d} 3-$ (4-(2-Furyl)benzoyl)pyridine was identified by GC as the main product. ${ }^{e}$ The product $7 \mathbf{e}$ could not be isolated; 2 chloro-3-(4-(2,4-dimethoxy-5-pyrimidyl)benzoyl)pyridine was identified by GC as the main product. ${ }^{f}$ 2-Phenyl-3(4-phenylbenzoyl)-6-(trifluoromethyl)pyridine was also formed in estimated 17\% yield. ${ }^{g}$ 2-Chloro-3-(3phenylbenzoyl)pyridine (9a') was also isolated in $41 \%$ yield. ${ }^{h}$ In addition to 10a' (Scheme 2, 23\% yield), three products resulting from mono (non-regioselective) and bis Suzuki cross-coupling were identified by GC, but no 4azafluorenone. ${ }^{i}$ In addition to 10a' (Scheme 2, 21\% yield), 2-phenyl-3-(2-phenylbenzoyl)pyridine (about 21\% yield) was also formed.

When 2-chloro-3-(2-chlorobenzoyl)pyridine (3-Cl) was involved in the reaction with phenylboronic acid, a mixture of products was obtained. Three products resulting from mono (non-regioselective) and bis Suzuki cross-coupling were identified by GC, but no 4-azafluorenone. Indeed, the cyclized product that could be isolated in $23 \%$ yield rather proved to be the aza $9 H$-tribenzo[a,c,e]cyclohepten-9-one 
10a' (entry 11, Scheme 2). The latter could result from a Suzuki cross-coupling followed by an intramolecular direct arylation between the phenyl group thus introduced and the second halogen. The ketone 10a' was also isolated starting from 2-chloro-3-(2-bromobenzoyl)pyridine (3-Br), this time in 21\% yield together with 8-phenyl-4-azafluorenone (10a, Figure 1, about 31\% yield) and 2-phenyl-3-(2phenylbenzoyl)pyridine (about $21 \%$ yield) (entry 12 ).
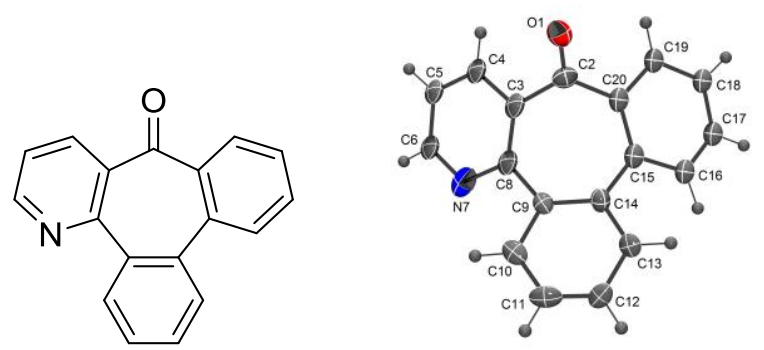

Scheme 2. Side compound 10a' obtained from 3 and ORTEP diagram (50\% probability).
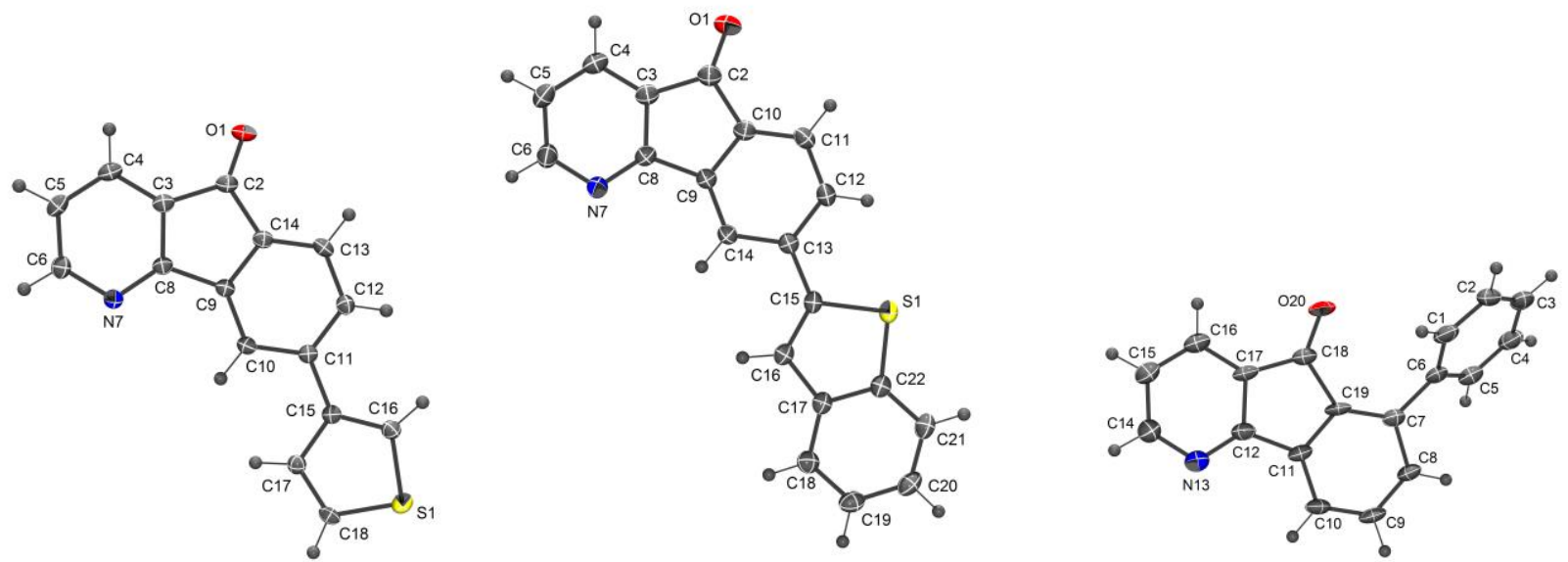

Figure 1. ORTEP diagram (50\% probability) of 7c, 7d and $\mathbf{1 0 a}$.<smiles>[Y]c1[Y4]cc(C(=O)c2ccccc2)c(Cl)n1</smiles>

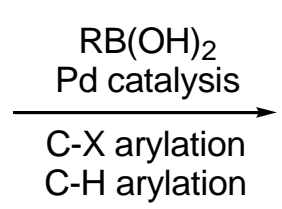<smiles>[R]c1ccc2c(n1)-c1ccccc1C2=O</smiles>

Scheme 3. Possible synthesis of 4-azafluorenones substituted on their pyridine ring using palladiumcatalyzed double functionalization. 
Also using palladium-catalyzed Suzuki coupling-intramolecular arylation auto-tandem reactions, we next focused on the synthesis of 4-azafluorenones substituted on their pyridyl ring by starting from different 3-benzoyl-2-chloro halogenopyridines (Scheme 3).

Our first goal was to identify a new method to synthesize onychine ( $\mathrm{R}=1-\mathrm{Me})$, an alkaloid endowed with anticandidal activity, ${ }^{1 \mathrm{a}}$ as well as analogs, in order to evaluate them for their biological activity. Ray and co-workers recently reported the direct palladium-catalyzed conversion of $\alpha$-aryl-2-bromo-3pyridylmethanols into 4-azafluorenones by oxidative intramolecular Heck cyclization using catalytic $\mathrm{Pd}(\mathrm{OAc})_{2}$ and $\mathrm{NaOAc}\left(2.5\right.$ equiv) in DMF at $100{ }^{\circ} \mathrm{C} .{ }^{8}$ Since we could not apply the deprotometalationaroylation sequence to 2-chloro-4-iodopyridine in order to prepare 3-benzoyl-2-chloro-4-iodopyridine (Table 1, entry 7), we first used these conditions to attempt Suzuki coupling-oxidation-intramolecular arylation auto-tandem reactions from $\alpha$-aryl-2-chloro-4-iodo-3-pyridylmethanols.

By starting from 2-chloro-4-iodopyridine, ${ }^{18}$ deprotolithiation using LiTMP (1 equiv) in THF at -70 ${ }^{\circ} \mathrm{C}$ furnished, after subsequent trapping with 4-anisaldehyde, the expected alcohol 11. Unfortunately, applying the conditions optimized by Ray and co-workers in the presence of phenylboronic acid only afforded 2-chloro-3-(4-methoxybenzoyl)-4-phenyl pyridine (oxidized monocoupled product) and its dechlorinated derivative. Under the conditions used in Table 2, oxidation proved incomplete and cyclization was not observed. Replacing $\mathrm{K}_{2} \mathrm{CO}_{3}$ by $\mathrm{KOAc}$ led to complete oxidation but inefficient cyclization (expected azafluorenone formed in a yield $<5 \%$ ) and competitive dechlorination. Using methylboronic acid instead of phenylboronic acid led to similar results (Scheme 4).<smiles>Clc1cc(I)ccn1</smiles>

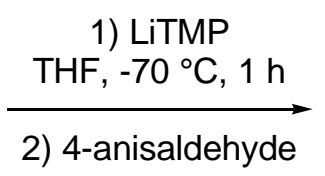

$(70 \%$ yield $)$<smiles>COc1ccc(C(O)c2c(I)ccnc2Cl)cc1</smiles>

11
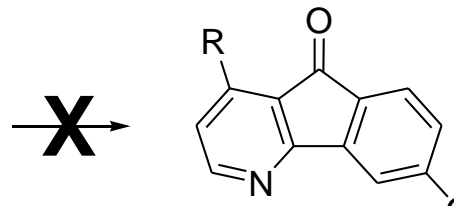

$\mathrm{R}=\mathrm{Ph}$ or $\mathrm{Me}$

Scheme 4. Attempted synthesis of 1-substituted 4-azafluorenones using a palladium-catalyzed Suzuki coupling-oxidation-intramolecular arylation auto-tandem reaction. 
The direct conversion of 2-chloro-4-bromopyridine to 3-benzoyl-4-bromo-2-chloropyridines using deprotometalation-aroylation being possible (Table 1, entries 6 and 7), we applied the conditions used in Table 2 to these ketones (Table 3). By using $\mathrm{Pd}(\mathrm{OAc})_{2}$ as transition metal source, $\mathrm{Cy}_{3} \mathrm{P}$ as ligand and $\mathrm{K}_{2} \mathrm{CO}_{3}$ as base in $\mathrm{DMF}$ at $130{ }^{\circ} \mathrm{C}$, the reaction performed from 3-benzoyl-4-bromo-2-chloropyridine (5$\mathbf{B r}$ ) in the presence of phenylboronic acid led to 1-phenyl-4-azafluorenone (12a) in 73\% yield (entry 1). Nevertheless, modulating the reactants nature showed that the reaction result was dependent on the nature of the arylboronic acids. By using 4-methoxyphenylboronic acid, the expected 1-substituted 4azafluorenone 12b was also isolated, but in a lower $52 \%$ yield (Figure 2 ). This result could be due to a less efficient cyclization, uncyclized 3-benzoyl-2-chloro-4-(4-methoxyphenyl)pyridine (Suzuki coupling product, $\mathbf{1 2} \mathbf{b}^{\prime}$ ) being also isolated in $24 \%$ yield (entry 2 ). In the case of 4 -aminophenylboronic acid, no 1-substituted 4-azafluorenone was detected by GC analysis of the crude, but only 2,4-bis(4aminophenyl)-3-benzoylpyridine (resulting from a double Suzuki coupling) and 4-(4-aminophenyl)-3benzoyl-2-chloropyridine (corresponding to the uncyclized product) (entry 3). These results show that the presence of an electron-donating group on the phenyl substituent at the 4 position of the pyridine ring is not suitable for a subsequent palladium-catalyzed cyclization. Unfortunately, employing 3pyridylboronic acid furnished a complex mixture in which the expected 1-substituted 4-azafluorenone was not identified (entry 4). An azafluorenone was neither detected with 2-thienylboronic acid, but the corresponding uncyclized Suzuki coupling product 12c', which was isolated in 49\% yield (entry 5). In the case of 2-benzo[b]thienylboronic acid, a complex mixture was produced, but from which the expected 1-substituted 4-azafluorenone $\mathbf{1 2 d}$ could be isolated in 10\% yield (entry 6). By turning to methylboronic acid, it proved possible to generate onychine (1-methyl-4-azafluorenone, 12e), an alkaloid endowed with anticandidal activity. ${ }^{1 \mathrm{a}}$ The moderate $52 \%$ yield obtained is due to the competitive formation of the bis-coupled product (about 11\% yield) and to a difficult palladiumcatalyzed cyclization, as demonstrated by the detection by GC of 3-benzoyl-2-chloro-4-methylpyridine (about 7\% yield) (entry 7). That the nature of the substituents has an impact on the course of the 
reaction was also evidenced by performing the reaction from 4-bromo-2-chloro-3-(3methoxybenzoyl)pyridine (6); in the presence of methylboronic acid, the reaction did not provide any more an azafluorenone, but the uncyclized Suzuki coupling product 13e' (entry 8). Attempts to cyclize 2-chloro-3-(3-methoxybenzoyl)-4-methylpyridine (13e') in a separate reaction under the same reaction conditions neither proved successful.

Table 3. Suzuki coupling-intramolecular arylation from the dihalides 5-Br and $\mathbf{6}$.<smiles>COc1cccc(C(=O)c2c(Br)ccnc2Cl)c1</smiles>

$$
\begin{gathered}
\mathrm{RB}(\mathrm{OH})_{2}(1 \text { equiv) } \\
\mathrm{Pd}(\mathrm{OAc})_{2}(5 \mathrm{~mol} \%) \\
\mathrm{Cy}_{3} \mathrm{P} \cdot \mathrm{HBF}_{4}(10 \mathrm{~mol} \%) \\
\underset{\mathrm{K} \mathrm{K}_{2} \mathrm{CO}_{3}(2 \text { equiv })}{\mathrm{DMF}, 130^{\circ} \mathrm{C}, 24 \mathrm{~h}}
\end{gathered}
$$

\begin{tabular}{|c|c|c|c|}
\hline Entry & Substrate $(-X)$ & Product (R) & Yield $^{a}(\%)$ \\
\hline 1 & 5-Br & 12a $(\mathrm{Ph})$ & 73 \\
\hline 2 & $5-\mathrm{Br}$ & $\mathbf{1 2 b}\left(\mathrm{C}_{6} \mathrm{H}_{4}-4-\mathrm{OMe}\right)$ & $52^{b}$ \\
\hline 3 & $5-\mathrm{Br}$ & $-\left(\mathrm{C}_{6} \mathrm{H}_{4}-4-\mathrm{NH}_{2}\right)$ & $--^{c}$ \\
\hline 4 & $5-\mathrm{Br}$ & - (3-pyridyl) & $-{ }^{d}$ \\
\hline 5 & 5-Br & - (2-thienyl) & $-e^{e}$ \\
\hline 6 & 5-Br & 12d (2-benzo $[b]$ thienyl) & $10^{f}$ \\
\hline 7 & $5-\mathrm{Br}$ & $12 \mathrm{e}(\mathrm{Me})$ & $52^{g}$ \\
\hline 8 & 6 & - (Me) & $-{ }^{h}$ \\
\hline
\end{tabular}

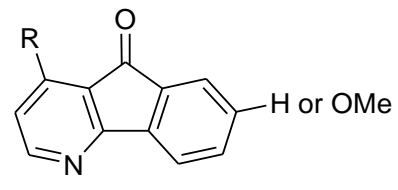

${ }^{a}$ After purification by column chromatography. ${ }^{b}$ 3-Benzoyl-2-chloro-4-(4-methoxyphenyl)pyridine (12b') was also isolated in $24 \%$ yield. ${ }^{c}$ Only 3-benzoyl-2,4-bis(4-aminophenyl)pyridine and 4-(4-aminophenyl)-3-benzoyl-2chloropyridine were identified by GC. ${ }^{d}$ A complex mixture was obtained. ${ }^{e}$ Only 3-benzoyl-2-chloro-4-(2-

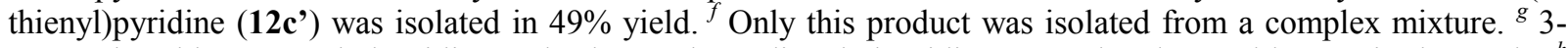
Benzoyl-2-chloro-4-methylpyridine and 3-benzoyl-2,4-dimethylpyridine were also detected by GC in the crude. ${ }^{h}$ Only 2-chloro-3-(3-methoxybenzoyl)-4-methylpyridine (13e') was isolated in 35\% yield.

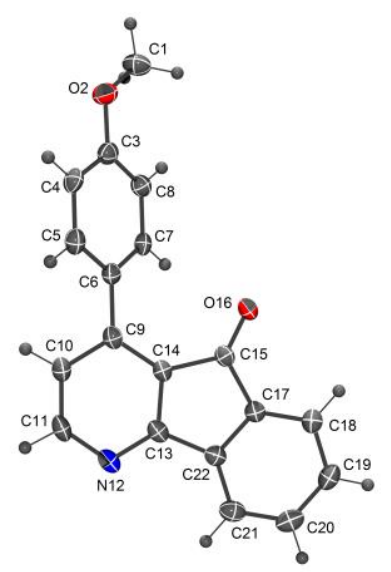

Figure 2. ORTEP diagrams ( $50 \%$ probability) of compound $\mathbf{1 2 b}$. 
In order to reach other analogs of onychine, deprotocupration-aroylation was first attempted from 2chloro-4-methylpyridine. Unfortunately, reaction of 2-chloro-4-methylpyridine under the conditions used in Table 1 and using benzoyl chloride as electrophile did not lead to the 3-pyridyl ketone, but to a mixture of unidentified compounds.

Compared with 3-benzoyl-4-bromo-2-chloropyridine (5-Br), 3-benzoyl-2,4-dichloropyridine (5-Cl) behaved differently. Indeed, under the conditions of Table 3 and in the presence of phenylboronic acid, the azafluorenone 12a was not obtained. Instead, due to a favored Suzuki coupling at the pyridine 2 position, ${ }^{19}$ 1-phenyl-2-azafluorenone was rather identified, but in a low $11 \%$ yield due to the competitive formation of 3-benzoyl-2,4-diphenylpyridine (double Suzuki coupling, 26\% yield), 3benzoyl-4-chloro-2-phenylpyridine (uncyclized product, 12\% yield) and 3-benzoyl-2-phenylpyridine (dechlorination of the latter, 3\% yield) (Scheme 5, left). In the case of 3-benzoyl-2,6-dichloropyridine (14), using phenylboronic acid demonstrated a favored Suzuki coupling at the less hindered pyridine 6 position, as shown by the formation of 3-phenyl-4-azafluorenone (15, 38\% yield), which was identified by X-ray diffraction. ${ }^{16}$ Nevertheless, such a reactivity difference is small, and the bis-coupled product was competitively formed in $52 \%$ yield (Scheme 5, right). We thus turned to 2,3- and 2,5dichloropyridines, which generally react regioselectively in Suzuki cross-coupling reactions to afford the 2-functionalized derivatives. ${ }^{20}$
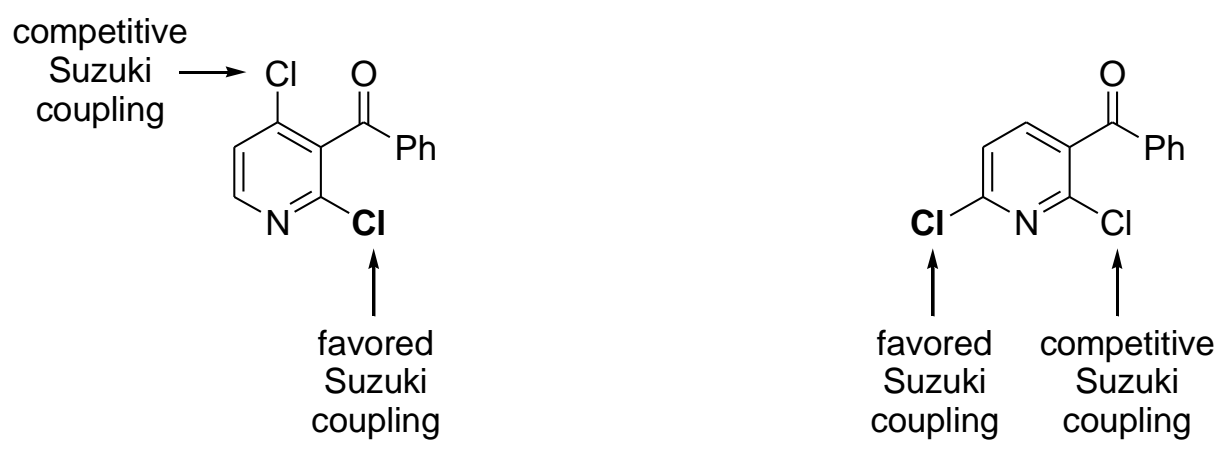

Scheme 5. Uncomplete regioselectivity observed for Suzuki coupling on the dichlorides 5-Cl and 14.

From 4-benzoyl-2,3-dichloropyridine (16), applying the same protocol in the presence of phenylboronic acid furnished 4-phenyl-3-azafluorenone (17, Figure 3) in 70\% yield. The product 
resulting from a double Suzuki coupling was also identified, but this time in about $15 \%$ yield. Similarly, 2-phenyl-3-azafluorenone (18) was synthesized from 4-benzoyl-2,5-dichloropyridine (19) in $64 \%$ yield (Scheme 6).<smiles>O=C(c1ccccc1)c1ccnc(Cl)c1Cl</smiles><smiles>O=C(c1ccccc1)c1cc(Cl)ncc1Cl</smiles>

19

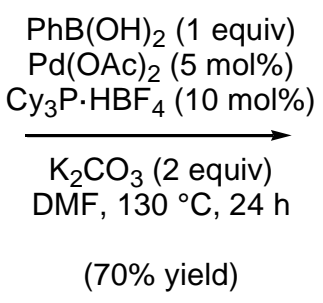

$\mathrm{PhB}(\mathrm{OH})_{2}$ (1 equiv) $\mathrm{Pd}(\mathrm{OAc})_{2}(5 \mathrm{~mol} \%)$ $\mathrm{Cy}_{3} \mathrm{P} \cdot \mathrm{HBF}_{4}(10 \mathrm{~mol} \%)$ $\mathrm{K}_{2} \mathrm{CO}_{3}$ (2 equiv) DMF, $130^{\circ} \mathrm{C}, 24 \mathrm{~h}$ (64\% yield)<smiles>O=C1c2ccccc2-c2c1ccnc2-c1ccccc1</smiles>

17<smiles>O=C1c2ccccc2-c2cnc(-c3ccccc3)cc21</smiles>

18

Scheme 6. Suzuki coupling-intramolecular arylation from the dichlorides $\mathbf{1 6}$ and $\mathbf{1 8 .}$

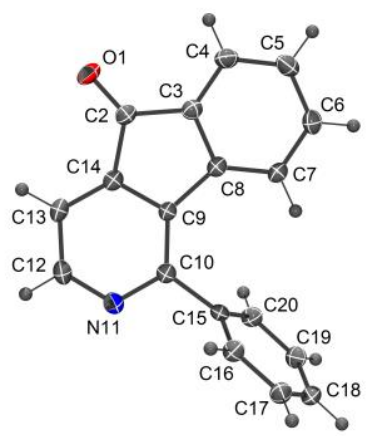

Figure 3. ORTEP diagrams (50\% probability) of compound 17.

Our experimental findings show that Suzuki coupling precedes intramolecular arylation during azafluorenone formation. To rationalize the results obtained for these cyclizations, we have performed quantum chemical calculations. One can predict that oxidative addition is quite related to the partial positive charge on the carbon bearing the chlorine, as it is for nucleophilic substitution. We thus accounted for this positive charge by linking it to the corresponding ${ }^{1} \mathrm{H}$ NMR chemical shift of the dechlorinated substrate, as shown by Handy and Zhang. ${ }^{21}$ As far as the C-H activation step is concerned, it notably depends on the corresponding $\mathrm{CH}$ acidity. Thus, in addition to the electrophilicity 
measure of the carbon bearing chlorine, we also calculated the acidity at the cyclization site of the phenyl ring for the expected Suzuki coupling products using a homodesmic reaction protocol effective for azines ${ }^{10 \mathrm{c}, 22}$ (Table 4).

Table 4. Calculated values of $\mathrm{p} K_{\mathrm{a}}$ (THF) for selected substrates, and ${ }^{1} \mathrm{H}$ NMR chemical shift for their dechlorinated analogues.

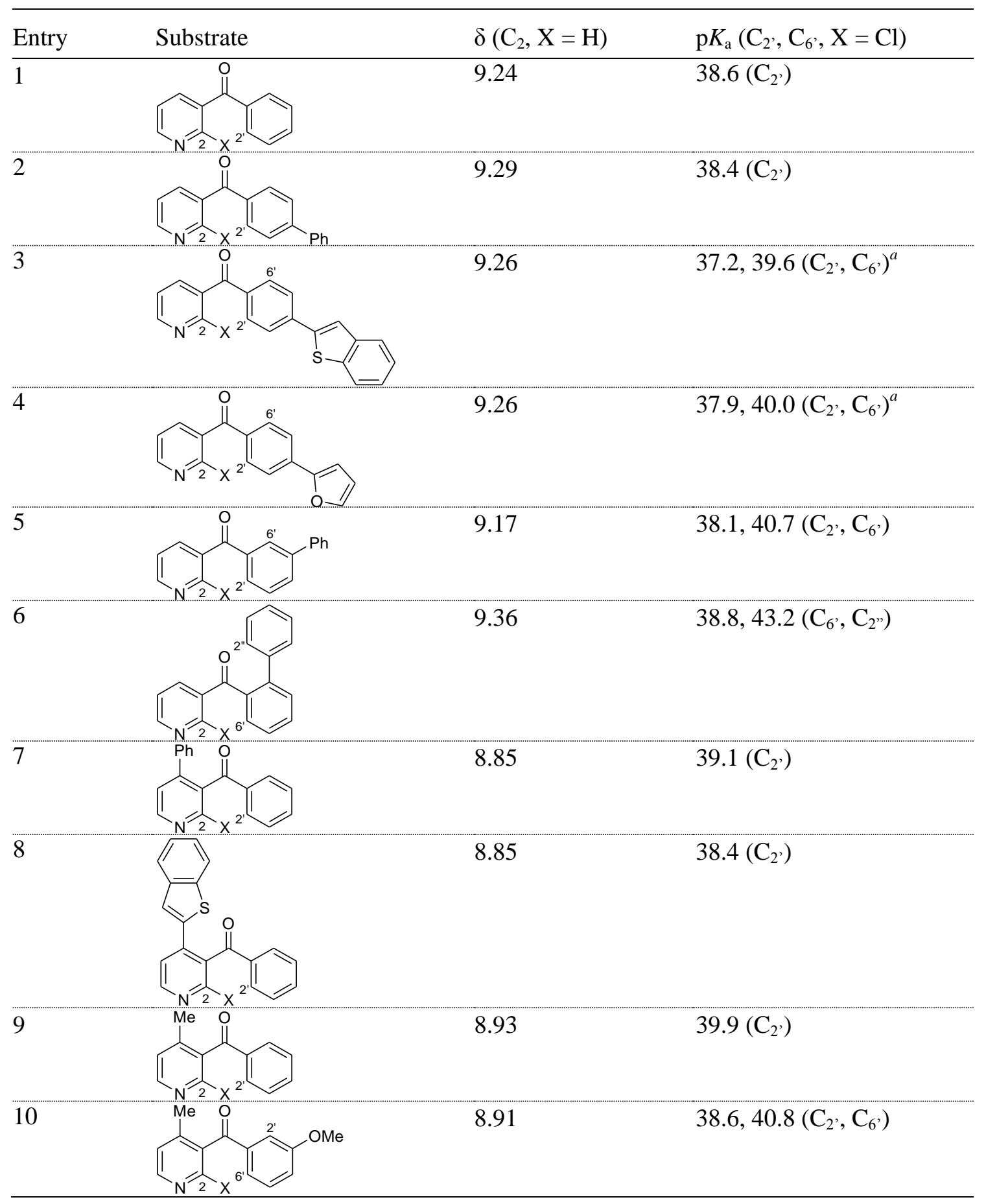

${ }^{a}$ Two values are given when distinct products can be obtained as a result of internal rotation. 
Because of the strict steric requirements for cyclization, we only considered here the $\mathrm{CH}$ acidities of the suspicious sites, omitting the others. It is obvious that some of these compounds exist in form of several rotamers, and the data from Table 4 refer to the most stable ones (see Supplementary data). In general, these polycycles demonstrate a trend, which is present in phenyl rings (rather than pyridyl) to be in conjugation with a carbonyl moiety. Unfortunately, in our set of compounds, the reaction center is quite remote from the substituent that is changed. This leads to their effect attenuation, and quantities discussed $\left(\delta, \mathrm{p} K_{\mathrm{a}}\right)$ are varying in a narrow range. Nevertheless, their change is quite logical with the electron-withdrawing or -donating properties (in particular, see entries 7-10).

We have previously demonstrated that $\mathrm{CH}$ acidities ${ }^{10 \mathrm{c}, 22}$ are an essential factor in deprotometallation of azines including biaryls. In the tandem process under consideration, one can see that the $\mathrm{p} K_{\mathrm{a}}$ 's contribution is not so important, but the electron-withdrawing groups still favor the reaction (e.g. see Table 2, entries 2-5; Table 3, entries 1,2).

When compared with 3-benzoyl-2-chloropyridine (Table 4, entry 1 ), ${ }^{12 \mathrm{~b}}$ the phenyl- and 2benzo $[b]$ thienyl-substituted derivatives coming from 1-Br (entries 2 and 3), which have nearly the same partial positive charges at $\mathrm{C} 2$ and $\mathrm{CH}$ acidities at $\mathrm{C}^{\prime}$ ', are converted into the tricycles $7 \mathbf{a}$ and $7 \mathbf{d}$ in similar (good) yields. The reason why the furyl-substituted derivative coming from 1-Br (entry 4) only furnished the dechlorinated Suzuki coupling product 3-(4-(2-furyl)benzoyl)pyridine does not seem to be in relation with these quantities.

To rationalize the lower reactivity of the phenyl-substituted derivative coming from 2 (entry 5), one can advance a lower partial positive charge at $\mathrm{C} 2$ when estimated from the ${ }^{1} \mathrm{H}$ NMR chemical shift of the dechlorinated substrate. On the same basis, a high partial positive charge at $\mathrm{C} 2$ is evidenced from the phenyl-substituted derivative coming from $\mathbf{3}-\mathbf{B r}$ (entry 6). This could be at the origin of the formation of the bis-coupled product 2-phenyl-3-(2-phenylbenzoyl)pyridine. The latter appears as a more likely precursor of $\mathbf{1 0 a}$ ' if we consider the low $\mathrm{CH}$ acidity at $\mathrm{C} 2$ " of the calculated substrate (entry 6). 
Compared with 3-benzoyl-2-chloropyridine (entry 1), the corresponding 4-phenyl (entry 7), 4-(2benzo $[b]$ thienyl) (entry 8) and 4-methyl (entry 9) derivatives show lower partial positive charges at $\mathrm{C} 2$ when estimated from the ${ }^{1} \mathrm{H}$ NMR chemical shift of the dechlorinated substrates. In the case of 4phenyl (entry 7) and 4-methyl (entry 9), it is combined with lower $\mathrm{CH}$ acidities at C2' but with nearly no alteration of the cyclization yield. Thus, the complex mixture obtained from the 4-(2benzo $[b]$ thienyl) (entry 8 ) has to be explained differently, and could result from possible coordination of palladium by the sulfur-containing ring. The reluctance to react of 2-chloro-3-(3-methoxybenzoyl)-4methylpyridine (entry 10) could result from both a sterically congested position at C2' and a lower $\mathrm{CH}$ acidity at C6'.

\section{Biological evaluation}

Because of structural similarity with natural azafluorenone antimicrobial agents such as onychine, ${ }^{1 \mathrm{a}, 2 \mathrm{~b}}$ the synthesized compounds $\mathbf{7 b - d}, \mathbf{9 a}, \mathbf{9 b}, \mathbf{1 0 a}, \mathbf{1 2 a}, \mathbf{b}, \mathbf{1 7}$ and $\mathbf{1 8}$ were screened for their antibacterial activity against Gram-negative (Escherichia coli) and Gram-positive (Staphylococcus aureus) bacteria, and for their antifungal activity against Candida albicans (Table 5). It was found that all the tested compounds have high potent antifungal activity against Candida albicans, more than the reference drug (nystatin). For the antibacterial activity, all the compounds except $\mathbf{9 b}$ and $\mathbf{1 8}$ have high to moderate effect against Gram-positive bacteria (Staphylococcus aureus) and, in case of Gram-negative bacteria (Escherichia coli), the compounds 9b, 12a,b and 18 exhibit high activities and the compounds 9a', 10a' and $\mathbf{1 7}$ moderate activities whereas the compounds $\mathbf{7 b - d}$ were found to have no effect.

Table 5. Bactericidal and fungicidal activity of the compounds $\mathbf{7 b - d}, \mathbf{9 a}, \mathbf{9 b}, \mathbf{1 0 a}, \mathbf{1 2 a}, \mathbf{b}, \mathbf{1 7}, 18$ and ciprofloxacin and nystatin. ${ }^{a}$

\begin{tabular}{lllll}
\hline Entry & Compound & Escherichia coli & Staphylococcus aureus & Candida albicans \\
\hline 1 & $\mathbf{7 b}$ & - & +++++ & +++++ \\
2 & $\mathbf{7 c}$ & - & +++ & ++++++ \\
3 & $\mathbf{7 d}$ & - & ++++ & ++++++ \\
4 & $\mathbf{9 a}$ & ++ & ++++ & ++++++ \\
5 & $\mathbf{9 b}$ & ++++++ & - & ++++++ \\
6 & $\mathbf{1 0 a}$ & +++ & ++++ & ++++++ \\
\hline
\end{tabular}




\begin{tabular}{|c|c|c|c|c|}
\hline 7 & $12 \mathbf{a}$ & ++++++ & ++ & ++++++ \\
\hline 8 & $12 b$ & ++++ & +++ & ++++++ \\
\hline 9 & 17 & +++ & +++ & ++++++ \\
\hline 10 & 18 & ++++++ & - & ++++++ \\
\hline 11 & ciprofloxacin & ++++ & ++++ & - \\
\hline 12 & nystatin & - & - & ++++ \\
\hline
\end{tabular}

${ }^{a}$ The diameters of zones of inhibition are given in mm. Stock solution: $5 \mu \mathrm{g}$ in $1 \mathrm{~mL}$ of DMF; $0.1 \mathrm{~mL}$ of stock solution in each hole of each paper disk. +: <15 mm; ++: 15-24 mm; +++: 25-34 mm; ++++: 35-44 mm, etc.

Onychine (12e) being one of the main alkaloids of the antimalarial plant Polyalthia debilis, ${ }^{2 \mathrm{~b}}$ the synthesized compounds $\mathbf{8 a}, \mathbf{1 0 a}, \mathbf{1 2 a}, \mathbf{b}, \mathbf{b}^{\prime}, \mathbf{d}, \mathbf{e}$ and $\mathbf{1 8}$ with structural analogy to onychine were also screened for their antimalarial activity (Table 6). Onychine $(\mathbf{1 2 e})$ presented only a weak activity $\left(\mathrm{IC}_{50}=\right.$ $52.4 \mu \mathrm{M})$ against the cloroquine sensitive strain 3D7 of Plasmodium falciparum. The majority of the tested compounds presented a similar or slightly higher activity to onychine. Only compounds 8a and 18, with $\mathrm{IC}_{50}$ of respectively 13.8 and $4.8 \mu \mathrm{M}$, were clearly highly active. According to Pink et al., a compound could be considered as an antiparasitic hit if its activity in vitro is $\leq 1 \mu \mathrm{g} / \mathrm{mL}$ and if it bears a selectivity towards mammalian cells of about tenfold. ${ }^{23}$ The compound $\mathbf{1 8}$, bearing no cytotoxicity at 10 $\mu \mathrm{M}$ and a quite interesting antiplasmodial activity $(4.8 \mu \mathrm{M}-1.2 \mu \mathrm{g} / \mathrm{mL})$, meets this criteria and could constitute an interesting antimalarial lead for further chemical modifications.

Table 6. Antimalarial activity of the compounds 8a, 10a', 12a,b,b',d,e and 18 .

\begin{tabular}{llll}
\hline Entry & Compound & $\mathrm{IC}_{50}(\mu \mathrm{g} / \mathrm{mL})$ & $\mathrm{IC}_{50}(\mu \mathrm{M})$ \\
\hline 1 & $\mathbf{8 a}$ & 4.51 & 13.8 \\
2 & $\mathbf{1 0 a}$ & 10.5 & 40.8 \\
3 & $\mathbf{1 2 a}$ & 6.37 & 24.7 \\
4 & $\mathbf{1 2 b}$ & 7.64 & 26.6 \\
5 & $\mathbf{1 2 b}$ & 10.3 & 31.8 \\
6 & $\mathbf{1 2 d}$ & 10.9 & 34.9 \\
7 & $\mathbf{1 2}$ & 10.2 & 52.4 \\
8 & $\mathbf{1 8}$ & 1.23 & 4.78 \\
\hline
\end{tabular}

Finally, a study has been carried out to investigate the cytotoxic potential of the derivatives $\mathbf{7 b - d , ~} \mathbf{9 b}$, and 12a,b (Table 7). The antiproliferative activity of the derivatives was determined using breast cancer cell line MCF-7, which is an invasive differentiated mammary epithelial breast cancer cell line used worldwide to screen and compare the antiproliferative activity of new molecules vs standard anticancer 
compounds. Among the molecules tested, the compounds 7c,d containing a thienyl ring showed a strong antiproliferative activity, higher to that exhibited by doxorubicin, whereas the compound 12b showed a similar activity.

Table 7. Cytotoxic activity of the compounds $\mathbf{7 b - d}, \mathbf{9 b}$, and 12a,b and doxorubicin against MCF-7. ${ }^{a}$

\begin{tabular}{lll}
\hline Entry & Compound & $\mathrm{IC}_{50}(\mu \mathrm{g} / \mathrm{mL})$ \\
\hline 1 & $\mathbf{7 b}$ & 4.43 \\
2 & $\mathbf{7 c}$ & 3.38 \\
3 & $\mathbf{7 d}$ & 2.78 \\
4 & $\mathbf{9 b}$ & 7.43 \\
5 & $\mathbf{1 2 a}$ & 8.48 \\
6 & $\mathbf{1 2 b}$ & 3.83 \\
7 & doxorubicin & 3.53
\end{tabular}

${ }^{a}$ IC50 is defined as the concentration which results in a $50 \%$ decrease in the cell number as compared with that of the control structures in the absence of an inhibitor.

\section{Conclusion}

In summary, different azafluorenones endowed with potential biological activities were synthesized from dihalogenated diaryl ketones by palladium-catalyzed Suzuki coupling-intramolecular arylation auto-tandem reactions. The required diaryl ketones were previously generated by sequential deprotocupration-aroylation. From 3-benzoyl-2-chloropyridines halogenated on their phenyl ring, several 6-arylated and 7-arylated 4-azafluorenones were prepared. Onychine (1-methylated 4azafluorenone) and 1-arylated analogs were synthesized by involving 3-benzoyl-4-bromo-2chloropyridine in the auto-tandem process. Finally, the access to 2-arylated and 4-arylated 3azafluorenones proved possible in two steps from commercially available 2,5-dichloropyridine and 2,3dichloropyridine.

\section{Experimental Section}

4.1. General. All reactions were performed in Schlenk tubes under an argon atmosphere. THF was distilled over sodium/benzophenone. DMF was dried over $\mathrm{CaH}_{2}$ and distilled before use. Liquid chromatography separations were achieved on silica gel Merck-Geduran Si 60 (63-200 $\mu$ m). Nuclear 
Magnetic Resonance spectra were acquired using Bruker AC-300 spectrometer (300 MHz and $75 \mathrm{MHz}$ for ${ }^{1} \mathrm{H}$ and ${ }^{13} \mathrm{C}$ respectively). ${ }^{1} \mathrm{H}$ chemical shifts $(\delta)$ are given in ppm relative to the residual solvent peak, and ${ }^{13} \mathrm{C}$ chemical shifts relative to the central peak of the solvent signal. ${ }^{24}$ High resolution mass spectrometry measurements were performed at the Centre Régional de Mesures Physiques de l'Ouest (CRMPO) in Rennes. 3-(4-Bromobenzoyl)-2-chloropyridine (1-Br), 2-chloro-3-(3bromobenzoyl)pyridine (2), 2-chloro-3-(4-iodobenzoyl)pyridine (1-I), 3-(4-bromobenzoyl)-2-chloro-6(trifluoromethyl)pyridine (4), 2-chloro-3-benzoyl-4-bromopyridine (5-Br), 8-phenyl-5H-indeno[1,2b]pyridin-5-one or 6-phenyl-4-azafluorenone (7a), 8-(4-hydroxyphenyl)-5H-indeno[1,2-b]pyridin-5-one or 6-(4-hydroxyphenyl-4-azafluorenone (7b), 8-phenyl-2-(trifluoromethyl)-5H-indeno[1,2-b]pyridin-5one or 6-phenyl-3-(trifluoromethyl)-4-azafluorenone (8a), 7-phenyl-5H-indeno[1,2-b]pyridin-5-one or 7-phenyl-4-azafluorenone (9a), 2-chloro-3-(3-phenylbenzoyl)pyridine (9a'), 7-(4-hydroxyphenyl)-5Hindeno[1,2-b]pyridin-5-one or 7-(4-hydroxyphenyl-4-azafluorenone (9b), 4-phenyl-5H-indeno[1,2b]pyridin-5-one or 1-phenyl-4-azafluorenone (12a), 3-benzoyl-2-chloro-4-(4-methoxyphenyl)pyridine (12b'), 4-methyl-5H-indeno[1,2-b]pyridin-5-one or 1-methyl-4-azafluorenone (onychine, 12e), 2methyl-5H-indeno[1,2-b]pyridin-5-one or 3-phenyl-4-azafluorenone (15), and 3-phenyl-5H-indeno[1,2c]pyridin-5-one or 2-phenyl-3-azafluorenone (18) were obtained as described in the preliminary communication. $^{16}$

X-ray Crystallography. The samples were studied with graphite monochromatized Mo-K $\alpha$ radiation $(\lambda=0.71073 \AA)$. The X-ray diffraction data were collected using APEXII, Bruker-AXS diffractometer at $T=150(2) \mathrm{K}$. All structures were solved by direct methods using the SIR97 program, ${ }^{25}$ and then refined with full-matrix least-square methods based on $F^{2}$ (SHELX-97) ${ }^{26}$ with the aid of the WINGX program. ${ }^{27}$ All non-hydrogen atoms were refined with anisotropic atomic displacement parameters. $\mathrm{H}$ atoms were finally included in their calculated positions. Molecular diagrams were generated by ORTEP-3 (version 2.02). ${ }^{27}$ 


\subsection{General procedure 1: Deprotonation using the lithium-copper base prepared from $\mathrm{CuCl}(1$}

equiv) and LiTMP ( 2 equiv) before trapping with an aroyl chloride. A stirred cooled $\left(0{ }^{\circ} \mathrm{C}\right)$ solution of LiTMP prepared at $0{ }^{\circ} \mathrm{C}$ in THF $(6 \mathrm{~mL})$ from 2,2,6,6-tetramethylpiperidine $(1.7 \mathrm{~mL}, 10$ mmol) and BuLi (1.6 M hexanes solution, $10 \mathrm{mmol})$ was treated with TMEDA (0.77 mL, 5.0 mmol) and $\mathrm{CuCl}(495 \mathrm{mg}, 5.0 \mathrm{mmol})$. The mixture was stirred for $15 \mathrm{~min}$ at $0{ }^{\circ} \mathrm{C}$ before introduction of the required substrate $(5 \mathrm{mmol})$. After $2 \mathrm{~h}$ at $\mathrm{rt}$, a solution of the required aroyl chloride $(10 \mathrm{mmol})$ in $\mathrm{THF}$ $(3 \mathrm{~mL})$ was added. The mixture was stirred at $\mathrm{rt}$ or $60{ }^{\circ} \mathrm{C}$ overnight before addition of a $1 \mathrm{M}$ aqueous solution of $\mathrm{NaOH}(20 \mathrm{~mL})$ and extraction with $\mathrm{Et}_{2} \mathrm{O}(2 \times 20 \mathrm{~mL})$. After washing the organic phase with an aqueous saturated solution of $\mathrm{NH}_{4} \mathrm{Cl}(10 \mathrm{~mL})$ and drying over anhydrous $\mathrm{Na}_{2} \mathrm{SO}_{4}$, the solvent was evaporated under reduced pressure, and the product was isolated after purification by flash chromatography on silica gel (the eluent is given in the product description).

4.2.1. 2-Chloro-3-(2-bromobenzoyl)pyridine (3-Br) was prepared from 2-chloropyridine according to the general procedure 1 and isolated (eluent: heptane/AcOEt 9/1) as a yellow oil (yield: $64 \%$ ): ${ }^{1} \mathrm{H}$ NMR (300 MHz, acetone- $\left.d_{6}\right)$ 7.52-7.63 (m, 4H), 7.74-7.78 (m, 1H), $8.0(\mathrm{dd}, 1 \mathrm{H}, J=7.6$ and $1.9 \mathrm{~Hz})$,

$8.60(\mathrm{~d}, 1 \mathrm{H}, J=4.8$ and $1.9 \mathrm{~Hz}) ;{ }^{13} \mathrm{C} \mathrm{NMR}\left(75 \mathrm{MHz}\right.$, acetone-d $\left.{ }_{6}\right) 120.9(\mathrm{C}), 124.0(\mathrm{CH}), 128.8(\mathrm{CH})$, $132.1(\mathrm{CH}), 134.2(\mathrm{CH}), 134.8(\mathrm{C}), 134.9(\mathrm{CH}), 140.0(\mathrm{C}), 140.8(\mathrm{CH}), 148.9(\mathrm{C}), 152.9(\mathrm{CH}), 193.9$ (C); HRMS (ASAP): calcd for $\mathrm{C}_{12} \mathrm{H}_{8}{ }^{79} \mathrm{Br}^{35} \mathrm{ClNO}\left([\mathrm{M}+\mathrm{H}]^{+}\right)$295.9478, found: 295.9480 .

4.2.2. 2-Chloro-4-bromo-3-(3-methoxybenzoyl)pyridine (6) was prepared from 4-bromo-2chloropyridine according to the general procedure 1 and isolated (eluent: heptane/AcOEt 9/1) as a pale yellow powder (yield: $31 \%$ ): $\mathrm{mp} 118^{\circ} \mathrm{C} ;{ }^{1} \mathrm{H}$ NMR $\left(300 \mathrm{MHz}, \mathrm{CDCl}_{3}\right) 3.88(\mathrm{~s}, 3 \mathrm{H}), 7.21(\mathrm{ddd}, 1 \mathrm{H}, J=$ 8.2, 2.6 and $1.0 \mathrm{~Hz}), 7.25-7.28(\mathrm{~m}, 1 \mathrm{H}), 7.37-7.42(\mathrm{~m}, 1 \mathrm{H}), 7.47(\mathrm{dd}, 1 \mathrm{H}, J=2.6$ and $1.6 \mathrm{~Hz}), 7.57(\mathrm{~d}$, $1 \mathrm{H}, J=5.3 \mathrm{~Hz}), 8.33(\mathrm{~d}, 1 \mathrm{H}, J=5.3 \mathrm{~Hz}) ;{ }^{13} \mathrm{C} \mathrm{NMR}\left(75 \mathrm{MHz}, \mathrm{CDCl}_{3}\right) 55.6\left(\mathrm{CH}_{3}\right), 113.1(\mathrm{CH}), 121.5$ $(\mathrm{CH}), 122.9(\mathrm{CH}), 126.9(\mathrm{CH}), 130.2(\mathrm{CH}), 131.8(\mathrm{C}), 135.9(\mathrm{C}), 136.1(\mathrm{C}), 148.1(\mathrm{C}), 150.1(\mathrm{CH})$, 160.3 (C), 191.2 (C); HRMS (ESI): calcd for $\mathrm{C}_{13} \mathrm{H}_{9}{ }^{79} \mathrm{Br}^{35} \mathrm{ClNNaO}_{2}\left([\mathrm{M}+\mathrm{Na}]^{+}\right)$347.94029, found: 347.9405 . 


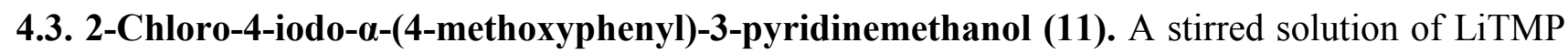
prepared at $0{ }^{\circ} \mathrm{C}$ in THF $(6 \mathrm{~mL})$ from 2,2,6,6-tetramethylpiperidine $(1.7 \mathrm{~mL}, 10 \mathrm{mmol})$ and $\mathrm{BuLi}(1.6$ $\mathrm{M}$ hexanes solution, $10 \mathrm{mmol}$ ) was stirred for $15 \mathrm{~min}$ before introduction, at $-70{ }^{\circ} \mathrm{C}$, of 2-chloro-4iodopyridine $^{18}(2.4 \mathrm{~g}, 10 \mathrm{mmol})$. After $1 \mathrm{~h}$ at $-70^{\circ} \mathrm{C}$, a solution of 4-anisaldehyde $(10 \mathrm{mmol})$ in $\mathrm{THF}(6$ $\mathrm{mL})$ was added. The mixture was stirred overnight before addition of water $(20 \mathrm{~mL})$ and extraction with $\mathrm{Et}_{2} \mathrm{O}(2 \times 20 \mathrm{~mL})$. After washing the organic phase with an aqueous saturated solution of $\mathrm{NH}_{4} \mathrm{Cl}$ $(10 \mathrm{~mL})$ and drying over anhydrous $\mathrm{Na}_{2} \mathrm{SO}_{4}$, the solvents were evaporated under reduced pressure, and the product was isolated after purification by flash chromatography on silica gel (eluent: heptane/AcOEt 8/2) as a pale yellow powder (yield: 70\%): mp $116{ }^{\circ} \mathrm{C} ;{ }^{1} \mathrm{H} \mathrm{NMR}\left(300 \mathrm{MHz}, \mathrm{CDCl}_{3}\right)$ $3.81(\mathrm{~s}, 3 \mathrm{H}), 5.65(\mathrm{~s}, 1 \mathrm{H}), 6.90(\mathrm{dd}, 2 \mathrm{H}, J=6.6$ and $2.1 \mathrm{~Hz}), 7.21(\mathrm{dd}, 2 \mathrm{H}, J=6.6$ and $2.1 \mathrm{~Hz}), 7.31(\mathrm{t}$, $1 \mathrm{H}, J=1.0 \mathrm{~Hz}), 7.68(\mathrm{t}, 1 \mathrm{H}, J=1.0 \mathrm{~Hz}), \mathrm{OH}$ not seen; ${ }^{13} \mathrm{C} \mathrm{NMR}\left(75 \mathrm{MHz}, \mathrm{CDCl}_{3}\right) 55.4\left(\mathrm{CH}_{3}\right), 73.5$ $(\mathrm{CH}), 114.5(2 \mathrm{CH}), 115.4(\mathrm{C}), 121.2(\mathrm{CH}), 128.3(2 \mathrm{CH}), 131.3(\mathrm{CH}), 133.7(\mathrm{C}), 150.5(\mathrm{C}), 157.7(\mathrm{C})$, 159.8 (C); HRMS (ESI): calcd for $\mathrm{C}_{13} \mathrm{H}_{11}{ }^{35} \mathrm{ClINNaO}_{2}\left([\mathrm{M}+\mathrm{Na}]^{+}\right)$: 397.94208 , found: 397.9424 .

4.4. General procedure 2: tandem reaction including Suzuki coupling. A degassed mixture containing $\mathrm{K}_{2} \mathrm{CO}_{3}(0.28 \mathrm{~g}, 2.0 \mathrm{mmol}), \mathrm{Pd}(\mathrm{OAc})_{2}(11 \mathrm{mg}, 50 \mu \mathrm{mol}, 5 \mathrm{~mol} \%), \mathrm{Cy}_{3} \mathrm{P} \cdot \mathrm{HBF}_{4}(37 \mathrm{mg}, 0.10$ $\mathrm{mmol}, 10 \mathrm{~mol} \%)$, the required ketone $(1.0 \mathrm{mmol})$ and the required boronic acid $(1.0 \mathrm{mmol})$ in $\mathrm{DMF}(4$ $\mathrm{mL})$ was heated at $130{ }^{\circ} \mathrm{C}$ for $24 \mathrm{~h}$. After filtration over a celite pad, washing using $\mathrm{CH}_{2} \mathrm{Cl}_{2}(3 \times 10$ $\mathrm{mL}$ ), and removal of the solvent under reduced pressure, the product was isolated after purification by flash chromatography on silica gel (the eluent is given in the product description).

\subsubsection{8-(3-Thienyl)-5H-indeno[1,2-b]pyridin-5-one or 6-(3-thienyl)-4-azafluorenone (7c) was} obtained from 1-Br and 3-thienylboronic acid using the general procedure 2 as described in the preliminary communication. ${ }^{16}$ X-ray diffraction data (CCDC 1405060): $\mathrm{C}_{16} \mathrm{H}_{9} \mathrm{NOS}, M=263.30$, monoclinic, space group $P{ }_{2} / c$ (I.T.\#14), $a=3.88380(10), b=23.6837(8), c=12.9204(4) \AA, \beta=$ $90.1350(10){ }^{\circ}, V=1188.45(6) \AA^{3}, Z=4, d=1.472 \mathrm{~g} . \mathrm{cm}^{-3}, \mu=0.260 \mathrm{~mm}^{-1}$; a final refinement on $F^{2}$ 
with 2699 unique intensities and 172 parameters converged at $\omega R\left(F^{2}\right)=0.1064(R(F)=0.0401)$ for 2246 observed reflections with $I>2 \sigma(I)$.

\subsubsection{8-(2-Benzo $[b]$ thienyl)-5H-indeno[1,2-b]pyridin-5-one $\quad$ or $\quad 6-(2-b e n z o[b]$ thienyl)-4-}

azafluorenone (7d) was obtained from 1-Br and 3-(2-benzo[b]thienyl)boronic acid using the general procedure 2 as described in the preliminary communication. ${ }^{16} \mathrm{X}$-ray diffraction data (CCDC 1405061): $\mathrm{C}_{20} \mathrm{H}_{11} \mathrm{NOS}, M=313.36$, monoclinic, space group $P$ 2 $1 / a$ (I.T.\#14), $a=7.9224(2), b=12.3724(4), c=$

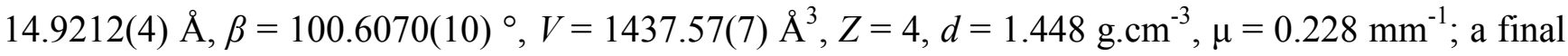
refinement on $F^{2}$ with 3280 unique intensities and 208 parameters converged at $\omega R\left(F^{2}\right)=0.1008(R(F)$ $=0.0379)$ for 2836 observed reflections with $I>2 \sigma(I)$.

4.4.3. 6-Phenyl-5H-indeno[1,2-b]pyridin-5-one or 8-phenyl-4-azafluorenone (10a) was obtained from 3-Br and phenylboronic acid using the general procedure 2. Identified by GC, its structure was confirmed by X-ray diffraction. X-ray diffraction data (CCDC 1405062): $\mathrm{C}_{18} \mathrm{H}_{11} \mathrm{NO}, M=257.28$, monoclinic, space group $P 2{ }_{1} / c$ (I.T.\#14), $a=3.8865(6), b=13.545(2), c=23.472(4) \AA, \beta=93.828(7)$ $\circ, V=1232.9(3) \AA^{3}, Z=4, d=1.386 \mathrm{~g} \cdot \mathrm{cm}^{-3}, \mu=0.086 \mathrm{~mm}^{-1}$; a final refinement on $F^{2}$ with 2809 unique intensities and 181 parameters converged at $\omega R\left(F^{2}\right)=0.1721(R(F)=0.0723)$ for 1311 observed reflections with $I>2 \sigma(I)$.

4.4.4. 9H-Tribenzo[a,c,e]cyclohepten-9-one (10a') was obtained from 3-Cl or 3-Br and phenylboronic acid using the general procedure 2 and isolated (eluent: heptane/AcOEt 9/1) as a pale yellow powder (yield: 23 or $21 \%$ ): $\mathrm{mp} 134{ }^{\circ} \mathrm{C} ;{ }^{1} \mathrm{H}$ NMR $\left(300 \mathrm{MHz}, \mathrm{CDCl}_{3}\right) 7.42(\mathrm{dd}, 1 \mathrm{H}, J=7.8$ and 4.7 Hz), $7.5(\mathrm{ddd}, 1 \mathrm{H}, J=7.5$ and 1.2 Hz), 7.55-7.62 (m, 2H), 7.64-7.69 (m, 2H), $7.73(\mathrm{dd}, 1 \mathrm{H}, J=7.7$ and 1.2 Hz), $7.76(\mathrm{dd}, 1 \mathrm{H}, J=7.8$ and $0.9 \mathrm{~Hz}), 8.05(\mathrm{dd}, 1 \mathrm{H}, J=7.8$ and $1.7 \mathrm{~Hz}), 8.17-8.22(\mathrm{~m}, 1 \mathrm{H})$, $8.88(\mathrm{dd}, 1 \mathrm{H}, J=4.7$ and $1.7 \mathrm{~Hz}) ;{ }^{13} \mathrm{C} \mathrm{NMR}\left(75 \mathrm{MHz}, \mathrm{CDCl}_{3}\right) 122.9(\mathrm{CH}), 127.1(\mathrm{CH}), 128.4(\mathrm{CH})$, $128.6(\mathrm{CH}), 129.9(\mathrm{CH}), 130.0(\mathrm{CH}), 131.1(\mathrm{CH}), 131.6(\mathrm{CH}), 132.2(\mathrm{CH}), 135.8(\mathrm{C}), 136.2(\mathrm{CH})$, 136.5 (C), 137.5 (C), 138.0 (C), 141.7 (C), 151.7 (CH), 153.1 (C), 196.9 (C); HRMS (ASAP): calcd for $\mathrm{C}_{18} \mathrm{H}_{12} \mathrm{NO}\left([\mathrm{M}+\mathrm{H}]^{+}\right)$258.0919, found: 258.0919. X-ray diffraction data (CCDC 1405063): 
$8\left(\mathrm{C}_{18} \mathrm{H}_{11} \mathrm{NO}\right), M=2058.22$, monoclinic, space group $P c(\mathrm{I} . \mathrm{T} . \# 7), a=7.4632(7), b=22.339(2), c=$

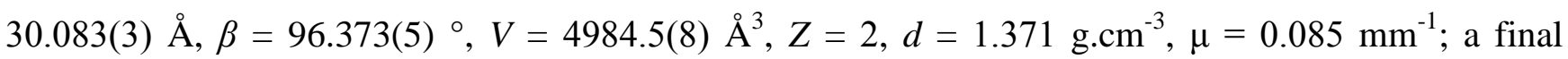
refinement on $F^{2}$ with 17035 unique intensities and 1039 parameters converged at $\omega R\left(F^{2}\right)=0.3947$ $(R(F)=0.1468)$ for 10255 observed reflections with $I>2 \sigma(I)$.

\subsubsection{4-(4-Methoxyphenyl)-5H-indeno[1,2-b]pyridin-5-one or 1-(4-methoxyphenyl)-4-} azafluorenone (12b) was obtained from 5-Br and 4-methoxyphenylboronic acid using the general procedure 2 as described in the preliminary communication. ${ }^{16}$ X-ray diffraction data (CCDC 1405064): $\mathrm{C}_{19} \mathrm{H}_{13} \mathrm{NO}_{2}, M=287.30$, orthorhombic, space group $F 2 d d(\mathrm{I} . \mathrm{T} . \# 43), a=3.8294(4), b=27.387(3), c=$ 52.389(5) $\AA, V=5494.3(10) \AA^{3}, Z=16, d=1.389 \mathrm{~g} . \mathrm{cm}^{-3}, \mu=0.091 \mathrm{~mm}^{-1}$; a final refinement on $F^{2}$ with 1781 unique intensities and 200 parameters converged at $\omega R\left(F^{2}\right)=0.101(R(F)=0.0461)$ for 1378 observed reflections with $I>2 \sigma(I)$.

\subsubsection{3-Benzoyl-2-chloro-4-(2-thienyl)pyridine (12c') was obtained from 5-Br and 2-} thienylboronic acid using the general procedure 2 and isolated (eluent: heptane/AcOEt 9/1) as a pale yellow powder (yield: 49\%): $\mathrm{mp} 102{ }^{\circ} \mathrm{C} ;{ }^{1} \mathrm{H} \mathrm{NMR}\left(300 \mathrm{MHz}, \mathrm{CDCl}_{3}\right) 7.01(\mathrm{dd}, 1 \mathrm{H}, J=5.1$ and 1.4 $\mathrm{Hz}), 7.25(\mathrm{dd}, 1 \mathrm{H}, J=5.0$ and $2.9 \mathrm{~Hz}), 7.3(\mathrm{dd}, 1 \mathrm{H}, J=2.9$ and $1.4 \mathrm{~Hz}), 7.34-7.43(\mathrm{~m}, 3 \mathrm{H}), 7.55(\mathrm{tt}$, $1 \mathrm{H}, J=6.8$ and $1.3 \mathrm{~Hz}), 7.72-7.75(\mathrm{~m}, 2 \mathrm{H}), 8.53($ br s, $1 \mathrm{H}) ;{ }^{13} \mathrm{C} \mathrm{NMR}\left(75 \mathrm{MHz}, \mathrm{CDCl}_{3}\right) 126.6(\mathrm{CH})$, $127.1(\mathrm{CH}), 127.5(\mathrm{CH}), 128.9(\mathrm{C}), 129.0(2 \mathrm{CH}), 129.5(2 \mathrm{CH}), 130.1(\mathrm{CH}), 134.3(\mathrm{CH}), 136.1(\mathrm{C})$, 136.6 (C), 138.0 (CH), 145.0 (C), 148.0 (C), 194.6 (C); HRMS (ASAP): calcd for $\mathrm{C}_{16} \mathrm{H}_{11}{ }^{35} \mathrm{CINOS}$ $\left([\mathrm{M}+\mathrm{H}]^{+}\right)$300.0250, found: 300.0248 .

\subsubsection{4-(2-Benzo[b]thienyl)-5H-indeno[1,2-b]pyridin-5-one or $\quad$ 1-(2-benzo[b]thienyl)-4-} azafluorenone (12d) was obtained from 5-Br and 2-(benzo[b]thienyl)boronic acid using the general procedure 2 and isolated (eluent: heptane/AcOEt 9/1) as a pale yellow powder (yield: 10\%): mp 186 ${ }^{\circ} \mathrm{C} ;{ }^{1} \mathrm{H}$ NMR $\left(300 \mathrm{MHz}, \mathrm{CDCl}_{3}\right)$ 7.41-7.46 (m, 3H), 7.49 (d, 1H, J=7.4 Hz), 7.64 (t, 1H, J= 7.0 Hz), $7.76(\mathrm{dd}, 1 \mathrm{H}, J=7.3$ and $0.7 \mathrm{~Hz}), 7.86-7.96(\mathrm{~m}, 3 \mathrm{H}), 8.60(\mathrm{br} \mathrm{s}, 1 \mathrm{H}), 8.70(\mathrm{~s}, 1 \mathrm{H}) ;{ }^{13} \mathrm{C} \mathrm{NMR}(75 \mathrm{MHz}$, $\left.\mathrm{CDCl}_{3}\right) 121.3(\mathrm{CH}), 122.3(\mathrm{CH}), 124.2(\mathrm{CH}), 125.1(\mathrm{CH}), 125.4(\mathrm{CH}), 126.4(\mathrm{CH}), 130.0(\mathrm{CH}), 131.6$ 
(CH), 134.7 (C), 135.5 (CH), 136.5 (C), 140.2 (C), 140.7 (C), 191.3 (C), 2CH and 4C not seen; HRMS (ASAP): calcd for $\mathrm{C}_{20} \mathrm{H}_{12} \mathrm{NOS}\left([\mathrm{M}+\mathrm{H}]^{+}\right)$314.0640, found: 314.0639 .

4.4.8. 2-Chloro-3-(3-methoxybenzoyl)-4-methylpyridine (13e') was obtained from 6 and methylboronic acid using the general procedure 2 and isolated (eluent: heptane/AcOEt 9/1) as a pale yellow powder (yield: 35\%): mp $92{ }^{\circ} \mathrm{C} ;{ }^{1} \mathrm{H}$ NMR (300 MHz, $\left.\mathrm{CDCl}_{3}\right) 2.22$ (s, 3H), 3.87 (s, 3H), 7.17$7.21(\mathrm{~m}, 2 \mathrm{H}), 7.23-7.26(\mathrm{~m}, 1 \mathrm{H}), 7.38(\mathrm{t}, 1 \mathrm{H}, J=7.8 \mathrm{~Hz}), 7.46(\mathrm{dd}, 1 \mathrm{H}, J=2.5 \mathrm{and} 1.6 \mathrm{~Hz}), 8.36(\mathrm{~d}$, $1 \mathrm{H}, J=5.1 \mathrm{~Hz}) ;{ }^{13} \mathrm{C} \mathrm{NMR}\left(75 \mathrm{MHz}, \mathrm{CDCl}_{3}\right) 19.3\left(\mathrm{CH}_{3}\right), 55.7\left(\mathrm{CH}_{3}\right), 113.0(\mathrm{CH}), 121.3(\mathrm{CH}), 122.8$ $(\mathrm{CH}), 124.5(\mathrm{CH}), 130.2(\mathrm{CH}), 135.1(\mathrm{C}), 137.2(\mathrm{C}), 147.2(\mathrm{C}), 148.2(\mathrm{C}), 149.6(\mathrm{CH}), 160.4(\mathrm{C})$, 194.1 (C); HRMS (ESI): calcd for $\mathrm{C}_{14} \mathrm{H}_{12}{ }^{35} \mathrm{ClNNaO}_{2}\left([\mathrm{M}+\mathrm{Na}]^{+}\right)$284.0454, found: 284.0450 .

4.4.9. 1-Phenyl-5H-indeno[1,2-b]pyridin-5-one or 4-phenyl-3-azafluorenone (17) was obtained from 16 and phenylboronic acid using the general procedure 2 as described in the preliminary communication. ${ }^{16}$ X-ray diffraction data (CCDC 1405065): $\mathrm{C}_{18} \mathrm{H}_{11} \mathrm{NO}, M=257.28$, monoclinic, space group $P 2{ }_{1} / c$ (I.T.\#14), $a=5.7543(5), b=21.827(2), c=10.2994(11) \AA, \beta=103.346(4){ }^{\circ}, V=$ 1258.7(2) $\AA^{3}, Z=4, d=1.358$ g.cm ${ }^{-3}, \mu=0.085 \mathrm{~mm}^{-1}$; a final refinement on $F^{2}$ with 2861 unique intensities and 181 parameters converged at $\omega R\left(F^{2}\right)=0.0942(R(F)=0.0446)$ for 1899 observed reflections with $I>2 \sigma(I)$.

4.5. In vitro antimicrobial and antifungal assays. Applying the agar plate diffusion technique, ${ }^{28}$ the compounds were screened in vitro for their bactericidal activity against Gram-positive bacteria (Staphylococcus aureus) and Gram-negative bacteria (Escherichia Coli), and for their fungicidal activity against Candida albicans. In this method, a standard $5 \mathrm{~mm}$ diameter sterilized filter paper disc impregnated with the compound $(0.3 \mathrm{mg} / 0.1 \mathrm{ml}$ of DMF) was placed on an agar plate seeded with the test organism. The plates were incubated for $24 \mathrm{~h}$ at $37^{\circ} \mathrm{C}$ for bacteria and $28{ }^{\circ} \mathrm{C}$ for fungi. The zone of inhibition of bacterial and fungi growth around the disc was observed.

4.6. In vitro antiplasmodial assay. Activity against $P$. falciparum chloroquine-sensitive $3 \mathrm{D} 7$ strains was assessed by following the procedure already described by Frederich et al. ${ }^{29}$ The parasites were 
obtained from Prof. Grellier (Museum d'Histoire Naturelle, Paris, France). Each alkaloid and extract was applied in a series of eight three-fold dilutions (final concentrations ranging from 0.09 to 200 $\mu \mathrm{g} / \mathrm{mL}$ for an extract and from 0.02 to $50 \mu \mathrm{g} / \mathrm{mL}$ for a pure substance) on two rows of a 96 -well microplate and were tested in duplicate $(n=2)$ or triplicate $(n=3)$. Parasite growth was estimated by determination of lactate dehydrogenase activity as described previously by Jonville et al. ${ }^{30}$ Artemisinin (98\%, Sigma-Aldrich) was used as positive control $\left(\mathrm{IC}_{50}=36 \pm 14 \mathrm{nM}\right)$. All compounds were tested 3 times $(n=3)$.

4.7. In vitro cytotoxicity. The compounds were tested against breast carcinoma cell line MCF-7. The method applied is similar to that reported by Skehan et al. ${ }^{31}$ using 20 sulfo-rhodamine-B stain (SRB). Cells were plated in 96-multiwell plate (104 cells/well) for $24 \mathrm{~h}$ before treatment with the test compound to allow attachment of cell to the wall of the plate. Different concentrations of the compound under test $(0,1.0,2.5,5.0$, and $10 \mathrm{mg} / \mathrm{mL})$ were added to the cell monolayer in triplicate wells in individual dose, and monolayer cells were incubated with the compounds for $48 \mathrm{~h}$ at $37^{\circ} \mathrm{C}$ and in atmosphere of $5 \% \mathrm{CO}_{2}$. After $48 \mathrm{~h}$, cells were fixed, washed and stained with SRB stain, excess stain was washed with acetic acid, and attached stain was recovered with Tris-EDTA buffer. Color intensity was measured in an ELISA reader, and the relation between surviving fraction and drug concentration is plotted to get the survival curve of the tumor cell line after the specified compound and the $\mathrm{IC}_{50}$ was calculated.

4.8. Theoretical calculations. All the calculations were performed at DFT B3LYP level of theory. The geometries were fully optimized using the 6-31G(d) basis set. In order to perform stationary point characterization and to calculate zero-point vibrational energies and thermal corrections, vibrational frequencies were calculated at the same level of theory. The single point energies were obtained using the $6-311+\mathrm{G}(\mathrm{d}, \mathrm{p})$ basis set and tight convergence criteria. ${ }^{1} \mathrm{H}$ NMR chemical shifts were calculated with Gauge-Independent Atomic Orbital (GIAO) method $^{32}$ using corresponding TMS shielding 
calculated at the same level of theory as the reference. The solvent effect was simulated within the polarized continuum model (PCM) with the default parameters for THF.

Acknowledgments. FM thanks the Institut Universitaire de France and Rennes Métropole for financial support. NM, FC and FM thank Thermo Fisher for generous gift of 2,2,6,6-tetramethylpiperidine.

Supplementary data. Supplementary data associated with this article can be found in the online version, at http://dx.doi.org/10.1016/j.tet.xxxxxxxxxxxxxxxxxxxxxxxxxxxxxxxxxxxxxx

\section{References and Notes}

1. (a) Hufford, C. D.; Liu, S.; Clark, A. M.; Oguntimein, B. O. J. Nat. Prod. 1987, 50, 961-964; (b) Wu, Y. C. Heterocycles 1989, 29, 463-475.

2. (a) Koyama, J.; Morita, I.; Kobayashi, N.; Osakai, T.; Usuki, Y.; Taniguchi, M. Bioorg. Med. Chem. Lett. 2005, 15, 1079-1082; (b) Prachayasittikul, S.; Manam, P.; Chinworrungsee, M.; Isarankura-Na-Ayudhya, C.; Ruchirawat, S.; Prachayasittikul, V. Molecules 2009, 14, 44144424; (c) Kraus, G. A.; Kempema, A. J. Nat. Prod. 2010, 73, 1967-1968; (d) Addla, D.; Bhima; Sridhar, B.; Devi, A.; Kantevari, S. Bioorg. Med. Chem. Lett. 2012, 22, 7475-7480.

3. Mueller, D.; Davis, R. A.; Duffy, S.; Avery, V. M.; Camp, D.; Quinn, R. J. J. Nat. Prod. 2009, 72, 1538-1540.

4. (a) Manpadi, M.; Uglinskii, P. Y.; Rastogi, S. K.; Cotter, K. M.; Wong, Y.-S. C.; Anderson, L. A.; Ortega, A. J.; Van Slambrouck, S.; Steelant, W. F. A.; Rogelj, S.; Tongwa, P.; Antipin, M. Y.; Magedov, I. V.; Kornienko, A. Org. Biomol. Chem. 2007, 5, 3865-3872; (b) Pumsalid, K.; Thaisuchat, H.; Loetchutinat, C.; Nuntasaen, N.; Meepowpan, P.; Pompimon, W. Nat. Prod. Commun. 2010, 5, 1931-1934; (c) Banjerdpongchai, R.; Khaw-On, P.; Ristee, C.; Pompimon, W. Asian Pacific journal of cancer prevention : APJCP 2013, 14, 2637-2641.

5. Shook, B. C.; Rassnick, S.; Osborne, M. C.; Davis, S.; Westover, L.; Boulet, J.; Hall, D.; Rupert, K. C.; Heintzelman, G. R.; Hansen, K.; Chakravarty, D.; Bullington, J. L.; Russell, R.; Branum, S.; Wells, K. M.; Damon, S.; Youells, S.; Li, X.; Beauchamp, D. A.; Palmer, D.; Reyes, M.; Demarest, K.; Tang, Y.-T.; Rhodes, K.; Jackson, P. F. J. Med. Chem. 2010, 53, 8104-8115.

6. (a) Bracher, F. Synlett 1991, 95-96; (b) Rebstock, A.-S.; Mongin, F.; Trecourt, F.; Queguiner, G. Tetrahedron 2003, 59, 4973-4977; (c) Rebstock, A.-S.; Mongin, F.; Trecourt, F.; Queguiner, G. Tetrahedron 2004, 60, 2181-2186; (d) Alessi, M.; Larkin, A. L.; Ogilvie, K. A.; Green, L. A.; Lai, S.; Lopez, S.; Snieckus, V. J. Org. Chem. 2007, 72, 1588-1594.

7. (a) Tu, S.; Jiang, B.; Jia, R.; Zhang, J.; Zhang, Y. Tetrahedron Lett. 2007, 48, 1369-1374; (b) Li, Y.; Fan, W.; Xu, H.-W.; Jiang, B.; Wang, S.-L.; Tu, S.-J. Org. Biomol. Chem. 2013, 11, 2417-2420.

8. $\quad$ Dhara, S.; Ahmed, A.; Nandi, S.; Baitalik, S.; Ray, J. K. Tetrahedron Lett. 2013, 54, 63-65.

9. (a) Mulvey, R. E.; Mongin, F.; Uchiyama, M.; Kondo, Y. Angew. Chem. Int. Ed. 2007, 46, 3802-3824; (b) Mulvey, R. E. Acc. Chem. Res. 2009, 42, 743-755; (c) Haag, B.; Mosrin, M.; Ila, H.; Malakhov, V.; Knochel, P. Angew. Chem. Int. Ed. 2011, 50, 9794-9824; (d) Mongin, F.; 
Uchiyama, M. Curr. Org. Chem. 2011, 15, 2340-2361; (e) Mongin, F.; Harrison-Marchand, A. Chem. Rev. 2013, 113, 7563-7727.

10. (a) Nguyen, T. T.; Chevallier, F.; Jouikov, V.; Mongin, F. Tetrahedron Lett. 2009, 50, 67876790; (b) Nguyen, T. T.; Marquise, N.; Chevallier, F.; Mongin, F. Chem. Eur. J. 2011, 17, 10405-10416; (c) Snégaroff, K.; Nguyen, T. T.; Marquise, N.; Halauko, Y. S.; Harford, P. J.; Roisnel, T.; Matulis, V. E.; Ivashkevich, O. A.; Chevallier, F.; Wheatley, A. E. H.; Gros, P. C.; Mongin, F. Chem. Eur. J. 2011, 17, 13284-13297; (d) Harford, P. J.; Peel, A. J.; Chevallier, F.; Takita, R.; Mongin, F.; Uchiyama, M.; Wheatley, A. E. H. Dalton Trans. 2014, 43, 1418114203.

11. (a) Campeau, L.-C.; Parisien, M.; Jean, A.; Fagnou, K. J. Am. Chem. Soc. 2006, 128, 581-590; (b) Alberico, D.; Scott, M. E.; Lautens, M. Chem. Rev. 2007, 107, 174-238; (c) Ackermann, L.; Vicente, R.; Kapdi, A. R. Angew. Chem. Int. Ed. 2009, 48, 9792-9826.

12. (a) Marquise, N.; Harford, P. J.; Chevallier, F.; Roisnel, T.; Wheatley, A. E. H.; Gros, P. C.; Mongin, F. Tetrahedron Lett. 2013, 54, 3154-3157; (b) Marquise, N.; Harford, P. J.; Chevallier, F.; Roisnel, T.; Dorcet, V.; Gagez, A.-L.; Sable, S.; Picot, L.; Thiery, V.; Wheatley, A. E. H.; Gros, P. C.; Mongin, F. Tetrahedron 2013, 69, 10123-10133.

13. (a) Miyaura, N.; Suzuki, A. Chem. Rev. 1995, 95, 2457-2483; (b) Kotha, S.; Lahiri, K.; Kashinath, D. Tetrahedron 2002, 58, 9633-9695.

14. Bräse, S.; de Meijere, A. Metal-Catalyzed Cross-Coupling Reactions (2nd Edition) 2004, 1, 217-315.

15. (a) Yadav, A. K.; Verbeeck, S.; Hostyn, S.; Franck, P.; Sergeyev, S.; Maes, B. U. W. Org. Lett. 2013, 15, 1060-1063; (b) Fogg, D. E.; dos Santos, E. N. Coord. Chem. Rev. 2004, 248, $2365-$ 2379.

16. Marquise, N.; Dorcet, V.; Chevallier, F.; Mongin, F. Org. Biomol. Chem. 2014, 12, 8138-8141.

17. Netherton, M. R.; Fu, G. C. Org. Lett. 2001, 3, 4295-4298.

18. Marzi, E.; Bigi, A.; Schlosser, M. Eur. J. Org. Chem. 2001, 1371-1376.

19. Dai, X.; Chen, Y.; Garrell, S.; Liu, H.; Zhang, L.-K.; Palani, A.; Hughes, G.; Nargund, R. J. Org. Chem. 2013, 78, 7758-7763.

20. (a) Maerten, E.; Sauthier, M.; Mortreux, A.; Castanet, Y. Tetrahedron 2006, 63, 682-689; (b) Brumfield, S.; Matasi, J. J.; Tulshian, D.; Czarniecki, M.; Greenlee, W.; Garlisi, C.; Qiu, H.; Devito, K.; Chen, S.-C.; Sun, Y.; Bertorelli, R.; Ansell, J.; Geiss, W.; Le, V.-D.; Martin, G. S.; Vellekoop, S. A.; Haber, J.; Allard, M. L. Bioorg. Med. Chem. Lett. 2011, 21, 7287-7290.

21. Handy, S. T.; Zhang, Y. Chem. Commun. 2006, 299-301.

22. Kadiyala, R. R.; Tilly, D.; Nagaradja, E.; Roisnel, T.; Matulis, V. E.; Ivashkevich, O. A.; Halauko, Y. S.; Chevallier, F.; Gros, P. C.; Mongin, F. Chem. Eur. J. 2013, 19, 7944-7960.

23. Pink, R.; Hudson, A.; Mouries, M.-A.; Bendig, M. Nat. Rev. Drug Discov. 2005, 4, 727-740.

24. Gottlieb, H. E.; Kotlyar, V.; Nudelman, A. J. Org. Chem. 1997, 62, 7512-7515.

25. Altomare, A.; Burla, M. C.; Camalli, M.; Cascarano, G. L.; Giacovazzo, C.; Guagliardi, A.; Moliterni, A. G. G.; Polidori, G.; Spagna, R. J. Appl. Crystallogr. 1999, 32, 115-119.

26. Sheldrick, G. M. Acta Crystallogr., Sect. A 2008, A64, 112-122.

27. Farrugia, L. J. J. Appl. Crystallogr. 2012, 45, 849-854.

28. Bauer, A. W.; Kirby, W. M.; Sherris, J. C.; Turck, M. Am. J. Clin. Pathol. 1966, 45, 493-496.

29. Frédérich, M.; Jacquier, M.-J.; Thepenier, P.; De Mol, P.; Tits, M.; Philippe, G.; Delaude, C.; Angenot, L.; Zeches-Hanrot, M. J. Nat. Prod. 2002, 65, 1381-1386.

30. Jonville, M.-C.; Dive, G.; Angenot, L.; Bero, J.; Tits, M.; Ollivier, E.; Frédérich, M. Phytochemistry 2013, 87, 157-163.

31. Skehan, P.; Storeng, R.; Scudiero, D.; Monks, A.; McMahon, J.; Vistica, D.; Warren, J. T.; Bokesch, H.; Kenney, S.; Boyd, M. R. J. Natl. Cancer Inst. 1990, 82, 1107-1112.

32. Ditchfield, R. Mol. Phys. 1974, 27, 789-807. 